\title{
Slang Language Acquisition, Construction, and Context of Used in Teenagers' Perspective of Batam City
}

\author{
Suhardianto \& Ambalegin \\ Universitas Putera Batam \\ (Suhardiantogamya@gmail.com\&Ambalegin@Yahoo.co.id)
}

\begin{abstract}
This study aims to find the acquisition, construction and perspectives of adolescents in the use of slang in the city of Batam. This research is a qualitative research used to examine the condition of natural objects where researchers are as a key instrument. In this study, researchers will conduct an investigation by collecting data directly or face to face with the source data and perform descriptive analysis without using statistical procedures or other calculations. The results showed that the formula in the acquisition and construction of slang languages can be seen from seven ways, among others: (a) Abbreviation, (b) Deletion, (c) Letter and sound change, (d) Adoption of Basic Word, (e) English or Indonesian-mixed abbreviation, (f) Citation from other slang languages, (g) New Construction. While the perspective of using slang among teenagers in communicating between them is $30.25 \%$ say, they use slang because they want to show other groups that they look more slick and cool, follow the times as much as $27.72 \%$, easier to communicate between them $21 \%$ Follow-up friends $7.56 \%$, funny $5.04 \%$, let famous $4.20 \%$ and custom $1.64 \%$.
\end{abstract}

Keywords: acquisition, construction, perspective, slang 
This research is a continuation study of slang language that has been done by the researchers themselves about the form of address slang (address forms) used by teenagers in the city of Batam in 2015 and published in the journal National NonAccredited BASIS Faculty of Language and Literature Putera Batam University. At this stage of the research, the researcher wanted to see further how the process of obtaining slang language, construction field, and context of its use as the development of research result of previous researcher. The next stage of the research the researcher plans to design a follow-up study to find the comparison of slang formation from mass time so that it can be seen whether slang language can contribute in Indonesian vocabulary or vice versa can destroy the standard Indonesian order. The results of this study are considered important because it is expected to be used as a reference in predicting the presence of slang in the future and prevent the use of slang language that destroys the grammatical Indonesian language standard.

This research is different from previous research, among others, (Gemilasari Nor, Jufrizal, 2013, p. 142), which focuses only on slang forms used in teen magazines "Aneka Yess!" and (Zhou, Yanchun, 2013, p. 209) from Changhun University of Science and Technology, China; Researching American slang to find the perspective, form and influence of its use in social life. In this study, the researchers sustainably want to see further starting from the process of acquisition, the realm of construction, the context of usage and defense of slang languages from the future that can be seen from various aspects of micro and macro linguistic studies.

Adolescents are communities that have a high level of creativity and productivity in creating new languages in their communities. Talk about slang language cannot be separated from the creativity of adolescent community. Slang is one of informal languages used by certain groups such as teenagers whose use is only done by their group and can only be understood by people in their own group. This statement is in accordance with the opinion of Yule in (Suhardianto, 2016, p. 56) he said that:

Slang is used for a very informal speech variety which often serves as an "in -group" language such as teenagers, army, pop group, etc. The word slang is used only known by the group itself. The word actually has informal language. The slang has been defines as one of those that everybody can recognize and nobody can define. Slang words almost could not be found in dictionary.

Yule's opinion above is also supported by (Trask, 2001, p. 146) he said that slang is a language that is difficult to understand by others but the concept of slang language itself can be understood by others. In general, the form of slang language is not in accordance with the existing standard language order. Its formation is variations of the formal language that is or may be formed with a new formula and is used for use by everyone in the group. Slang language changes from time to time so that it is temporary because it will change again when a person's adolescence changes. 
The acquisition of slang languages by adolescents is inseparable from the development of slang languages from time to time, where slang language grows because it is influenced by adolescent communities that exist in big cities through mass media, print and electronic. This evolving era, slang language is no longer only influenced by adolescent communities living in big cities such as Jakarta, Bandung, and Surabaya, but adolescents have established their own slang language within the community of its territory even though it has not been completely removed from outside influences. Batam city which is one of the destinations for immigrant from outside Batam area to settle including from big city like Jakarta, Bandung and Surabaya is considered still giving contribution in influencing the use of slang language itself in Batam city.

General language acquisition can be obtained through formal and informal levels. Acquisition of language from the formal level can be seen from the teaching-learning process conducted in formal institutions such as schools, universities, and courses. Language acquisition informally refers to the process of mastering a person's native language from birth. This view is in line with (Yule, 2010, p. 54) view of language acquisition. He said that the acquisition of the mother tongue is naturally or informally born through direct interaction with groups living in their midst such as mothers, fathers, older siblings, and other family groups while the acquisition of a second language is obtained through a formal process which can be in school or language learning place.
The phenomenon of acquiring slang as an informal language that has a different background to the form of languages obtained formally or informally certainly has a different way of obtaining it because slang language is not taught formally or informally to the youth community. Looking at the difference between the first and second formal and informal acquisition, the process of obtaining slang language becomes an interesting one to observe.

Slang language is one of the informal languages whose use includes all aspects of everyday language usage such as household domains, education, friendship, entertainment, and social culture. According to (Holmes, 2008, p. 223) the domain in linguistic terms refers to the election of language use on the social aspects prevailing in society in which there are speech participants and setting the occurrence of language use. Domain of language use classified into such as the family domain (mother, father, older brother, grandmother, and grandfather), the realm of friendship, the domain of religion, the realm of education and the realm of work.

The widespread use of slang languages in these realms certainly cannot be separated from the amount of creativity possessed by teenagers in creating new things in their community. The widespread use of slang languages will certainly lead to negatives in the prescribed standard Indonesian language. Knowing the ins and outs of the slang language can certainly be a guide in doing prevention against the negatives in question. In addition to the use of slang in certain spheres, slang language has also been 
widespread in all aspects of adolescent life. Slang is not only used in an informal context within the youth community but has been carried on in formal contexts such as school, workplace, and family life.

Looking at the phenomenon of slang use above, the researcher is interested to find out more about the acquisition process of slang language, construction field and its usage context so that the result can be used as guidance in preventing slang language that can destroy the standard language structure and encourage the use of slang in certain sphere Which can enrich the existing standard or formal language treasury.

\section{Sociolinguistics}

The use of slang is a social phenomenon that occurs in a particular community whose use is limited to those within the group such as the youth community. Slang language is also part of the language used in a society that cannot be separated from existing social activities. To be able to understand the phenomenon of the use of slang language in society then need to understand about the concept of sociolinguistic science which in fact is a science that examines the relationship of language use in the context of society.

(Stockwell, 2013, p. 11) holds that sociolinguistics is a science that examines the relationship between the uses of language in the context of existing societies. Thus, sociolinguistics deals with the social aspects contained in society. Sociolinguistics also discusses the different variations of language used in society in describing social phenomena such as the use of slang itself.
Thus, it can be concluded that sociolinguistics as a branch of macrolinguistic science that examines the relationship of language with social factors such as age, social status, community, occupation, religion, social culture, politics, etc.

Similar opinions about language and community relationships are also suggested by (Chaika, 2008, p. 479) that sociolinguistics is a science that explores the correlation of existing languages with variations of existing social factors such as participant, setting, topic, function, and social status that influence the use someone's language.

From both views on the concept of sociolinguistic science above it can be concluded that slang language as a phenomenon of language use in society cannot be separated from the influence of social aspects that apply such as someone's social status, education level, age, gender, kinship, and social Existing culture.

\section{Language Domain}

The slang language that is part of the communication tool within a particular group of communities such as adolescents is seen to have expanded the use of which has already penetrated to other domains previously used only in their communities. Theoretically, the language domain refers to the variations of language used in certain social and setting contexts. Selection of the language domain refers to the group or community in the community. There are several domains of language usage such as family domain, the realm of friendship, the 
domain of religion, the sphere of education and the realm of work. This opinion is consistent with Richard's view (Jack C. Richards, 2001, p.88) that the realm of language is the use of language that is determined by certain groups or communities in society. There are several different languages:

- Family domain

The use of language that refers to family groups such as in kinship or household environments such as father, mother, sister, older brother, grandparents are called as family domain

- The realm of friendship The use of language that refers to someone who has a relationship of friendship and age are the same age. The use of language in this domain is more intimate and informal in certain situations and conditions such as in the street, market, and restaurant. The form of language use in this realm is saya, loe, gue, and kamu.

- The domain of religion

The domain of language use in religious contexts refers to mosques, churches, and monasteries. The use of language in this realm is like ustadz, pastor and priest.

- Education sphere

The domain of language use in the context of schools and formal educational institutions that exist such as teachers, principals and students

- The realm of work.

The use of language in the realm of work refers to offices and factories. The use of language in this domain relates to the world of work and language used such as fathers, managers, supervisors, and employees.

\section{Language Style}

According to (Holmes, 2008, p. 11) variations in the use of language is determined by the purpose of use and associated with the user. The use of language is influenced by the place where the language is used and who the users are and whose language it is used.

\section{Kinds of Language Style}

In general, the style of language can be divided into two kinds of formal and informal language style, (Pardede, 2012, p. 115) Informal language style is the language used in the realm of social relations with the other person who has a close relationship like friends. While the style of formal language is the language used in the realm of a more formal and used on the opponent who has a higher social status.

From the above perspective, it can be concluded that slang is one of the informal languages used by the youth community in the group. Slang language is only used in circles or friends who are the same age with speakers in an informal context.

\section{Language Acquisition}

Language acquisition is the human process of gaining the ability to capture, produce, and use words for understanding and communication. This capacity involves various capabilities such as syntax, phonetics, and extensive vocabulary. The language obtained can be a vowel like in 
spoken or manual language like in sign language.

Language acquisition by (Yule, 2010, p. 42) is the process of a person mastering the language through stages called formal and informal stages. Formal stage is the process by which a person mastered the language through a formal process in the institutions of language learning, while the informal stage is the process of someone mastering the language naturally from the parent that is in the mastery of the mother tongue. In relation to slang languages obtained by adolescent communities outside of formal and informal processes, it can be seen that the slang is formed by teen creativity and their agreement in the process of formation. The acquisition of slang language becomes interesting to be studied because of different ways of obtaining such as acquisition of language in general.

\section{Slang language}

According to (Yule, 2010, p. 224) slang is used to communicate in a very informal form in a particular group such as teenagers, soldiers, pop groups, etc. The word slang used is only known by the group itself. Thus, slang language can only be defined by the people within the group itself. The slang words can hardly be found in the dictionary. Slang language is the same as the idiom language used in the informal communication domain.

Slang languages have traditionally been regarded as vulgar and abusive. Slang language reflects the use of language that is not polite in society. In the field of language, slang is considered taboo and is not allowed to appear in a formal social context. Slang language is one of the language styles used by teenagers and will always be developed and used to express themselves in the use of their language and can meet their needs in using language. (Zhou, Yanchun, 2013, p. 211)

\section{Slang Language Form}

The form of slang language consists of words and phrases. The use of slang language words depends on the context and it also applies to the phrase, (Paltridge, 2006, p. 46) Slang words formed by various processes include the following:

\section{Slang as Words and Phrases}

The word is a combination of letters that have meaning. In this study, researchers found the form of slang as a word in communication activities in adolescent groups such as, noun (N), verb (V), and adjective (Adj). Phrase is a combination of two or more words that have non-predicative characteristics. (Fasya, 2013, p. 99)

\section{Context}

According to (Trask, 2001, p. 120) the context is very dynamic and not rigid; It is constantly changing and evolving to adjust the situation and the existing environmental conditions. In a broad sense, context is used as a means of expressing the use of everyday language. Related to the use of slang language can be concluded that the slang language used in the teen community is very dynamic and extends to all existing communication context, both oral and written communications. 


\section{Method}

This research is a qualitative research used to examine the condition of natural objects where researchers are as key instrument. In this study, researchers will conduct an investigation by collecting data directly or face to face with the source data and perform descriptive analysis without using statistical procedures or other calculations.

This research was conducted in Batam city, Riau Islands province which is one of the immigration areas visited by many people from other regions or provinces in Indonesia. Site selection is focused on some districts that have densely populated population such as Batu Aji sub-district, Tiban sub-district and Batam Center subdistrict.

The populations in this study were all teenagers who reside or live in the three largest sub-districts in the city of Batam that is Batu Aji district, Tiban district and Batam Center sub-district. Indicator of adolescent age refers to expert opinion that is range of 12 - 19 years.

As a sample of the research, researchers took thirty adolescents (informants) in each sub-district so that ninety informants were randomly selected to be interviewed in a structured way to find the data needed in the study.

\section{Results and Discussion}

Slang Language Acquisition and Construction
After analyzing the data obtained from the teenagers, there are some constructions can be determined as the way how teenagers acquire and construct their slang language in their community. The way how the teenagers construct their slang can be shaped by abbreviation, deletion, letters and sound change, adopting of basic word sound, English or English-Indonesia Abbreviation, Citation, and new construction.

Forms of Slang Language "Abbreviation"

Table 1

Forms of slang language "Abbreviation"

No

Kinds of Slang Language

\begin{tabular}{lll} 
& Slang Forms & Example of Slang use \\
\hline 1 & GPL & GPL ya cayang \\
\hline 2 & TST & TST lah kita \\
\hline 3 & OJS & OJS buat kamu \\
\hline 4 & CLBK & $\begin{array}{l}\text { Kita harus CLBK } \\
\text { kembali }\end{array}$ \\
\hline 5 & PD & Dasar loe PD \\
\hline 6 & No-bar & Kita Nobar yok \\
\hline 7 & Tel-Mi & Dia Telmi \\
\hline 8 & Org & Kenapa sih to ORG \\
\hline
\end{tabular}

From the example in the table 1 above can be seen that teenagers when they construct slang language, they form by abbreviating the words. There are several ways of abbreviation done by teenagers, they are: (1) Initial each word collection such as exampel in a, b, c, d, and e above. The word GPL is abbreviated from "Gak Pakai Lama", TST is abbreviated from "Tau sama Tau", OJS is abbreviated from "Oh Aja Sih", CLBK is abbreviated from "Cinta Lama Bersemi Kembali", and PD is abbreviated from "Percaya Diri." (2) Initial 
sylable collectionsuch as example in $\mathrm{f}$ and $\mathrm{g}$ above. The "Nobar" is abbreviated from the words "Nonton Bareng", and "Telmi" is created from the words "Telat Mikir". (3)Word letter choosen such as in example $g$ above. The word "Org" is created from the word "Orang".

Forms of Slang Language "Deletion"

Table 2

Forms of slang language "Deletion"

\begin{tabular}{lll}
\hline \multirow{2}{*}{ No } & \multicolumn{2}{c}{ Kinds of Slang Language } \\
\cline { 2 - 3 } & Slang Forms & Example of Slang use \\
\hline 1 & Gi & Loe gi apa? \\
\hline 2 & $P a$ & Loe bicara pa ya? \\
\hline 3 & $Y a$ & $Y a$, aku mau \\
\hline
\end{tabular}

The forms and example of slang language use above can be defined that the teenagers in Batam construct the slang language bu deleting of initial letter and sylllable. It can be described below:

Deletion of initial syllable:

$G i$ is created from the word Lagi. To make slang the teenagers delete the syllable $L a$. It becomes $G i$ for slang that refers to the meaning of Lagi_to ask about kind of activity done by someone not asking about additional for something

Example: Loe $g i$ apa?

*Loe mau gi (unused) giapa?

Deletion of initial letter:

$P a$ is created from the word Apa. To make slang the teenagers delete the letter $A$. It becomes $P a$ forslang that refers to the meaning of Apa to ask about someone's need not asking about someone's activities

Example: Mau pa coy?

*Lagi pa coy?(unused)

$Y a$ is created from the word Iya. To make slang the teenagers delete the letter $I$. It becomes $Y a$ for slang that refers to the meaning of Iya to ask either about someone's need and activities.

Example: Loe mau ya? Loe gi apa $y a$ ?

Forms of Slang Language 'Lettersand Sound Change'

Table 3

Forms of slang language "Letters and sound Change"

No Kinds of Slang Language

\begin{tabular}{lll} 
& Slang Forms & Example of Slang use \\
\hline 1 & Makacih & Makacih ya sayang \\
\hline 2 & Kacian & Kacian sekali dia \\
\hline 3 & Cayang & Aku Cayang kamu \\
\hline 4 & Clalu & Kamu Clalu begitu \\
\hline 5 & Clamanya & $\begin{array}{l}\text { Aku suka kamu } \\
\text { Clamanya }\end{array}$ \\
\hline 6 & Qmu & Qmu mau kemana \\
\hline 7 & Dy & Dy udah tau \\
\hline 8 & Tw & Tw gue \\
\hline 9 & Maniz & Maniz bingit dia \\
\hline 10 & Imoet & Imoet ya cewek itu \\
\hline & &
\end{tabular}

The example of use and varities forms of slang in table 3 above can be concluded that teenager construct the slang language by changing the sound such as the sound "S" to 
sound "c", sound " $\mathrm{k}$ " to sound " $\mathrm{q}$ ", sound "ia" to sound " $y$ ", sound au to sound "w", and sound " $\mathrm{s}$ " to sound " $\mathrm{z}$ " as clearly explained below:

Change of "S" to letter "C"

Makacih is a replacement of the word Makasih or Terima Kasih. To make slang language the teenagers change the letter " $\mathrm{S}$ " to the letter " $\mathrm{C}$ " as example below:

\section{Example: Makacih \\ Makasih/Terima Kasih}

Kacian is a replacement of the word kasihan. To make slang language the teenagers change the letter " $\mathrm{S}$ " to the letter " $C$ " as example below:

Example: Kacian

Kasihan

Cayang is a replacement of the word Sayang. To make slang language the teenagers change the letter " $\mathrm{S}$ " to the letter " $C$ " as example below:

Example:

Cayang <

Sayang

Clamanya is a replacement of the word Selamanya. To make slang language the teenagers change the letter " $\mathrm{S}$ " to the letter " $\mathrm{C}$ " as example below:

Example: $\quad$ Clamanya < Selamanya

$\underline{\text { Clalu }}$ is a replacement of the word Selalu. To make slang language the teenagers change the letter " $\mathrm{S}$ " to the letter " $C$ " as example below:
Example: $\quad$ Clalu

Selalu

Change of " $\mathrm{K}$ " to letter "Q"

$Q m u$ is a replacement of the word $\underline{K a m u}$. To make slang language the teenagers change the letter " $\mathrm{K}$ " to the letter " $Q$ " as example below:

Example: $\underline{Q} m u$

$\underline{\text { Kamu }}$

Change of "Ia" to sound "Y"

Dy is a replacement of the word Dia.

To make slang language the teenagers change the sound "Ia" to the sound "Y" as example below:

Example: Dia $\quad$ <

$\underline{\text { Dy }}$

\section{Change of "Au" to sound "W"}

$T w$ is a replacement of the word Tau. To make slang language the teenagers change the sound "Au" to the sound "W" as example below:

Example: $\quad \underline{T} w$

Tau

Change of "S" to sound " $Z$ "

Maniz is a replacement of the word Manis. To make slang language the teenagers change the sound " $\mathrm{S}$ " to the sound "Z" as example below:

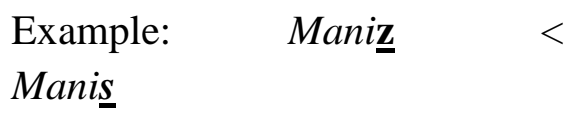

Change of "U" to sound "Oe"

Imoet is a replacement of the word Imut. To make slang language the 
teenagers change the sound " $U$ " to the sound "Oe" as example below:

Example: Imoet

$\operatorname{Im} \underline{\boldsymbol{u}} t$

Forms of Slang Language"Adopting Of Basic Word Sound"

Table 4

Forms of slang language "Adopting of Basic Word Sound"

\begin{tabular}{llll}
\hline No & \multicolumn{3}{c}{ Kinds of Slang Language } \\
\cline { 2 - 4 } & Slang Forms & $\begin{array}{l}\text { Example of } \\
\text { use }\end{array}$ & Slang \\
\hline 1 & Binggow/Bingits & $\begin{array}{l}\text { Dia } \\
\text { binggow/bingits }\end{array}$ \\
\hline 2 & Cemengut & $\begin{array}{l}\text { Cemenget } \\
\text { cayang }\end{array}$ \\
\hline 3 & Jehong & Qmu jehong ya \\
\hline 4 & Keles & Kamu keles kali \\
\hline
\end{tabular}

The examples in table 4 above describe the use and the construction of slang language done by teenager as explained below:

Binggow and Bingits are formed from the word Banget. These words are used to express or to describes something.

Example: Qmu Hebat binggow $=\mathrm{Qmu}$ cantik $\underline{\text { bingits }}$

Cemengut is formed from the word Semangat. This word is used to support someone to do something hard

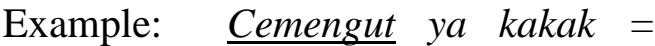
Semangat ya kakak
Jehong is formed from the word Jahat. This word is used to express someone's character

Example: Qmujehong ya =

\section{Kamu Jahat ya}

Keles is formed from the word Kali. This word is used to express or to emphasize about someone's opinion. This word is not used for counting or meas multiple.

Example: Iya tau $\underline{\text { Keles }}=$

Iya, sayasudah tahu tentang itu

$$
\text { * } 2 \text { keles } 2=4
$$

Forms of Slang Language "English or English-Indonesia Abbreviation"

Table 5

Forms of slang language " English or English-Indonesia Abbreviation"

\begin{tabular}{lll}
\hline No & \multicolumn{2}{c}{ Kinds of Slang Language } \\
\cline { 2 - 3 } & Slang Forms & $\begin{array}{l}\text { Example of Slang } \\
\text { use }\end{array}$ \\
\hline 1 & COPAS & Loe Copas ini ya \\
\hline 2 & OTW & Gue lagi OTW \\
\hline 3 & GWS & GWS ya kamu \\
\hline 4 & OMG & $\begin{array}{l}\text { OMG } \\
\text { binggow }\end{array}$ \\
\hline 5 & INTRO & Intro dong kamunya \\
\hline 6 & LOLA & Lola kali kamu ya \\
\hline 7 & WAKSELFIE & Ih dia Wakselfie \\
\hline
\end{tabular}

The data of slang and example of its use displyed on table 5 above described the way how teenagers in Batam to construct slang language in their community. The way used to construct slang is English or 
English-Indonesia abbreviation which is explained below:

English Language Abbreviation:

The word COPAS comes from the original of English language words of COPY PASTE. It combines to make slang language. The combination happened in the initial each syllable of words. $C O$ and $P A S$.

The word OTW comes from the original of English language words of ON THE WAY. It combines to make slang language. The combination happened in the initial each letter of words. $O, T$ and $W$.

The word $O M G$ comes from the original of English language words of $O H M Y G O D$. It combines to make slang language. The combination happened in the initial each letter of words. $O, M$ and $G$.

The word GWS comes from the original of English language words of GET WELL SOON. It combines to make slang language. The combination happened in the initial each letter of words. $G, W$ and $S$.

The word INTRO comes from the original of English language words of INTRODUCE. It takes two initial syllables of word to make slang language.

English - Indonesia Abbreviation:
The word LOLA comes from the original of English - Indonesia language words LOADING - LAMA. It combines to make slang language. The combination happened in the initial each syllable of English Indonesia words. $L O$ and $L A$.

The word WAK - SELFIE comes from the original of English - Indonesia regional language words of $A W A K$ and SELFIE. Awak is a word that is mostly used by Sumatra people refers to the first or third singular person. It combines to make slang language.

Forms of Slang Language "Citation"

Table 6

Forms of slang language "Citation"

\begin{tabular}{lll}
\hline No & \multicolumn{2}{c}{ Kinds of Slang Language } \\
\cline { 2 - 3 } & Slang Forms & Example of Slang use \\
\hline 1 & Loe & Loe mau kemana \\
\hline 2 & Gue & Gue suka loe \\
\hline 3 & Die & Die cantik sekali \\
\hline
\end{tabular}

The word Loe comes from the Jakarta language that refers to Кати or You in English language. This word is adopted by BatamTeenagers to use in their communication

The word Gue also comes from the Jakarta language that refers to Saya or $\underline{I}$ in English language. This word is adopted by BatamTeenagers to use in their communication

The word Die comes from the Jakarta language that refers to $\mathrm{Dia}$ or $\mathrm{He}$ or 
She in English language. This word is adopted by BatamTeenagers to use in their communication.

Forms of Slang Language "New Construction"

Table 7

Forms of slang language " New

Construction"

No Kinds of Slang Language

\begin{tabular}{lll} 
& Slang Forms & Example of Slang use \\
\hline $\mathbf{1}$ & Nyanting & $\begin{array}{l}\text { Nyanting dong } \\
\text { bukunya }\end{array}$ \\
\hline $\mathbf{2}$ & Relat & Kita rekat yok \\
\hline $\mathbf{3}$ & Tekong & Jangan tekong dong \\
\hline $\mathbf{4}$ & Badi & Dia badi ya \\
\hline $\mathbf{5}$ & Taken & Taken yok \\
\hline $\mathbf{6}$ & Rempong & Rempong kali dia \\
\hline $\mathbf{7}$ & Kepo & Kepo aja loe \\
\hline
\end{tabular}

Nyanting is slang language that refers to the meaning of Pinjam or borrow. No correlation form of pronunciation between the word nyanting and pinjam.

Relat is slang language that refers to the meaning of Jadian or make a relationship with boyfriend or girlfriend. No correlation form of pronunciation between the word Relat and Jadian.

Badi is slang language that refers to the meaning of Orang Gila or a crazy man. No correlation form of pronunciation between the word Badi and Orang Gila.

Taken is slang language that refers to the meaning of Merampas or carry away. No correlation form of pronunciation between the word Taken and Merampas.

Rempong is slang language that refers to the meaning of Banyak omong or fussy. No correlation form of pronunciation between rempong and banyak omong.

Kepo is slang language that refers to the meaning of Pengen Tau or to know curiously. No correlation form of pronunciation between the word Kepo and to know curiously.

Teenagers' Perspective in Use of Slang Language

Tabel 8

Teenager's Perspective in use of slang language

\begin{tabular}{llll}
\hline No & $\begin{array}{l}\text { Reason of } \\
\text { Using Slang }\end{array}$ & Amount & Percentage \\
\hline 1 & $\begin{array}{l}\text { Friends } \\
\text { influencing }\end{array}$ & 9 & $7.56 \%$ \\
\hline 2 & $\begin{array}{l}\text { Following to } 33 \\
\text { new era }\end{array}$ & $27.73 \%$ \\
\hline 3 & $\begin{array}{l}\text { To show off } 36 \\
\text { existence }\end{array}$ & $30.25 \%$ \\
\hline 4 & $\begin{array}{l}\text { Getting easy } 28 \\
\text { to } \\
\text { communicate }\end{array}$ & $21.00 \%$ \\
\hline
\end{tabular}




\begin{tabular}{llll}
\hline 6 & Being familiar & 5 & $4.20 \%$ \\
\hline 7 & Habit & 2 & $1.68 \%$ \\
\hline 8 & Having fun & 6 & $5.04 \%$ \\
\hline Total & 119 & $100 \%$ \\
\hline
\end{tabular}

Based on the data found by the researcher in interviewing the informants as displayed above, it can be concluded that the teenagers mostly use the slang language because of showing off others. It can be seen from the percentage of its use that is $30.25 \%$. Other mostly used reason of slang language by teenagers is following modern era that is $27.73 \%, 21 \%$ getting easy to communicate among them, $7.56 \%$ having fun, $4.20 \%$ becomming familiar and $1.64 \%$ habit factors.

\section{Conclusion}

From the data analysis above can be conclude that the forms of slang language that are used by teenagers in Batam can be formed in to several ways such as abbreviation which is divided into three categories are initial each word collection, initial syllable collection, and word letter chosen. The second way of slang language forms is deletion. It can be divided into deletion of initial letter and deletion of initial syllable. The third way is letters and sound change. It includes change of " $\mathrm{S}$ " to letter "C", change of " $\mathrm{K}$ " to letter "Q", change of sound "Ia" to sound "Y", change of sound " $A u$ " to sound "W", change of "S" to sound "Z", and change of sound " $U$ " to sound "Oe" such as Imoet is a replacement of the word Imut.
The fourth way of making slang language is adoption of basic word. For instance the words Binggow and Bingits are formed from the word Banget means very. The fifth way is called as English or English-Indonesia abbreviation for instance the word CoPas comes from the original of English language words of Copy Psteand the word LoLa comes from the original of English - Indonesia language words Loading-Lama. The sixth way of making slang language is citation such as the word Loe comes from the Jakarta language that refers to Катиаnd the word Gue also comes from the Jakarta language that refers to Saya. The last way of forming slang language that doneby teenagers is new construction. It refers to the new forms of slang language allegedly that are formed under arbitrariness. For instance the word Nyanting is slang language that refers to the meaning of Pinjam or borrow and word Badi is slang language that refers to the meaning of Orang GIla or a crazy man. The two of these words have no correlation of sound and form with the basic form of the word Pinjam and Gila.

The last result of this research is apparently teenagers' perspective in use of slang language. The reason of using slang language that is applied by teenagers in their community is to 'show off' their existence in society. It is declared by 36 informants or $30.25 \%$. Other reasons are the effect of modern era which is declared by 33 informants or $27.73 \%$, and getting easy to communicate is $21 \%$.

\section{References}

Chaika, E. (2008). Language the social 
miror. (Ne. L. Education, Ed.) (Fouth Edit). Canada: Cengage Learning Products. Retrieved from https://www.amazon.com/LanguageSocial-Sociolinguistics-ElaineChaika/dp/1424004322

Fasya, M. (2013). Variable Sosial Sebagai Penentu Penggunaan Slang Makian dalam Bahasa Indonesia. Masyarakat Linguistik Indonesia, 1, 81-102. Retrieved from http://www.academia.edu/6649221/Jur nal_Linguistik_Indonesia_Tahun_ke31_Nomor_1

Gemilasari Nor, Jufrizal, M. A. H. (2013). AN ANALYSIS OF WORD FORMATION OF SLANG WORDS FOUND IN. English Language and Literature E-Journal, volume 3, (September ISSN 2302-3546), 142148. Retrieved from http://onesearch.id/Record/IOS242.artic le-2403? widget=1\&repository_id=3369

Holmes, J. (2008). An Introduction to Sociolinguistics (Fourth Edi). LOndon and New York: Longman Malaysia. Retrieved from https://abudira.files.wordpress.com/201 2/08/full_summary_an_introduction_to _sociolinguistics.pdf

Jack C. Richards, J. C. T. S. R. (2001). Teaching English as a Foreign Language Approaches and Methods in Language Teaching. Cambridge University Press.

Paltridge, B. (2006). Discourse (second edi). Bodmin, Cornwall.London: MPG Ltd.

Pardede, H. (2012). Introduction to SOciolinguistics, From general to Local Perspective (fisrt edit). Jakarta: Halaman Moeka in Callaboration with LLC Publishing.
Stockwell, P. (2013). A Sociolinguistics A Resource book for student. France: Routledge is an imprint of the taylor \&France Group. Retrieved from https://www.google.co.id/webhp?sourc eid=chrome-

instant\&ion $=1 \&$ espv $=2 \&$ ie $=U T F-$

$8 \# q=i s b n+b u k u+$ stockwell $+a+$ socioling uistics+a+resource+book+for+students

Suhardianto. (2016). Batam Teenagers' Slang language: Shaping, Using, and Perspective. Jurnal Lateralisasi Bahasa Dan Sastra Indonesia, $1 \mathrm{~V}$, NomorO(Maret 2016 ISSN: 2354936X), 1-12. Retrieved from www.languageresearch2016.blogspot.c om

Trask, R. . (2001). A Student's Dictionary of Language and Linguistics (second edi). London: Oxfod University Press.

Yule, G. (2010). The Study of Language. (C. U. Press, Ed.) (Fourth Edi). New York: Cambridge University Press. Retrieved from

https://www.google.co.id/webhp?sourc eid=chrome-

instant\&ion $=1 \&$ espv $=2 \&$ ie $=U T F$ -

$8 \# q=i s b n$ buku george yule

Zhou, Yanchun, Y. F. (2013). A Sociolinguistic Study of American Slang. Theory and Practice in Language Studies, Vol. 3, No(Theory and practice in Language studies), 2209-2213. Retrieved from http://www.academypublication.com/is sues/past/tpls/vol03/12/08.pdf 